\title{
Structure of an RNA Interacting with the Stem-loop Sequence at the Gag-pol Junction
}

\author{
Bongrae Cho \\ Department of Applied Chemistry, Cheongit Linversity, Cheongiu 360-764, Korea. E-mail: brchoáciuac.kr \\ Received March 2, 2009. Accepted March 18, 2009
}

Key Words: Gag-pol junction. Stem-loop sequence. RNase TI. Nuclease SI. RNase VI

RNA structure has been analyzed by biophysical method such as NMR (nuclear magnetic resonance), which has not been popular because the RNA with small size only is available for the stnictural analysis with NMR. 'So biochemical methods using structure specific enzymes and chemicals have been used widely for the analysis of RNA structure. ${ }^{z \cdot 8}$ Enzymes and chemical which have mainly been used for probing RNA structure in solution, are double-strand-specific RNase VI. single-strand-specific miclease SI. RNase Tl which has a specificity for a guanine in single strand region. and kethoxal (3-ethoxy-1,1-dihydroxy-2-butanone). which modify the $\mathrm{Nl}$ and $\mathrm{N} 2$ of guanine in the single strand. Hydroxyl radical $(\cdot \mathrm{OH})$ has also been used for the structural analysis of RNA. Exposed nucleotides are damaged by hydroxyl radical while nucleotides involved in tertiary contacts are protected from damage. making it a favorable approach for establishing exterior/interior relations for RNA. ${ }^{\text {-15 }}$ Radicals are generated from Fe(II)-EDTA with hydrogen peroxide $\left(\mathrm{H}_{2} \mathrm{O}_{2}\right)$. Ascorbate (or DTT) is added to reduce $\mathrm{Fe}$ (III) to Fe(II). Hydrogen abstraction from the ribose $4^{\prime}$ carbon leads to strand scission. In-line probing is also an RNA-structure probing method recently developed by Breaker group. ${ }^{16.18}$ This method is used to examine secondary structure of RNAs and whether RNAs undergo stnictural rearrangements under the different incubation conditions. In-line probing takes advantage of the fact that the spontaneous cleavage of RNA is dependent on the local structure at each intemucleotide linkage. RNA degrades through a micleophilic attack by the 2'oxygen on the adjacent phosphorus. Cleavage occurs efficiently when the attacking 2 'oxygen. the phosphorus and the departing 5 ' oxygen of the phosphodiester linkage are in a linear configuration. Linkages in double strand region of a folded RNA show resistance to cleavage because it is difficult for the atoms to be held in an in-line configuration. However, if folding does not restrict its structure. linkages occasionally take on in-line geometry through random motion and therefore are subject to a spontaneous cleavage.

RNA aptamers which are capable of interacting with the stem-loop sequence at the gag-pol junction of HIV-l RNA. were selected from a random-sequence RNA library: ${ }^{19}$ In this

\section{GGGCGAAUAGGGAAGCUUGAU}

Figure 1. Sequence of the randomized region in RNA aptamer $13-1-15$. work the secondary structure of the RNA aptamer 13-1-15. one of the selected RNA aptamers (Fig. I) was examined with the MFOLD program accessed on the internet (nww bioinfo.rpi. edu/applications/mfold/old/rna) and with RNA structural probes such as RNase Tl. RNase V1 and nuclease S1. Because prior to getting the information for the interaction between an RNA aptamer and a hairpin RNA, the deternination of the structure of RNA aptamers is inportant. The secondary structure of RNA aptamer 13-1-15 was also compared with those of RNA aptamer 13-1-3 and 12-1-5. which were studied previously.

The stucture of RNA aptamer 13-1-15 was probed in binding buffer with RNase T1. RNase V1, and nuclease S1 (Fig. 2). G12, G23, G24 G29 and G33 were cleaved by RNase TI. especially strong cleavages at G5. Gl0 and Gll so these guanines are thought to be in single-strand region of the secondary structure model of RNA aptamer 13-1-15. But G19 and $\mathrm{G} 22$ in double-strand region were also digested by RNase $\mathrm{Tl}$. suggesting that these two Gs are unstable because Gl9 and $\mathrm{G} 22$ are near a bulge G33 and single strand region, respectively.
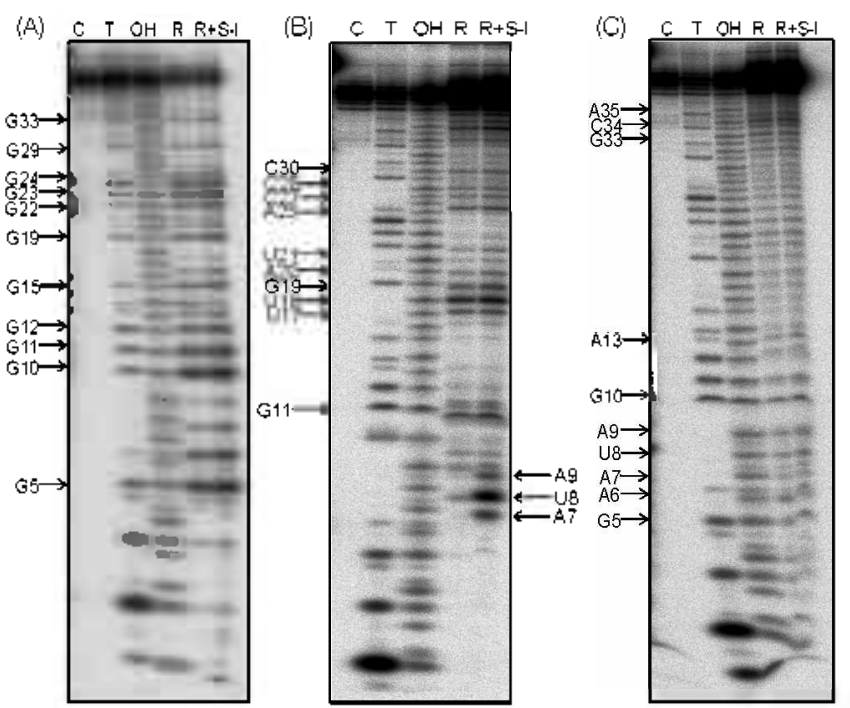

Figure 2. Enzymatic probing of RNA aptamer 13-1-15 labeled at the 5 -end. The RNA was partially digested with RNase Tl (A). RNase VI (B) and nuclease SI (C). The cleaved nucleotides are indicated by arrows. Region A7UA9 was protected from RNase VI digestion by the hairpin RNA. Lane C, control: lane T, the denatured RNA treated with RNase $\mathrm{T} 1$; lane $\mathrm{OH}$, partial alkaline ladder: lanes $\mathrm{R}$ and $\mathrm{R}+\mathrm{S}-\mathrm{l}$, enzymatic cleavages in the absence of and the presence of stem-loop RNA, respectively 


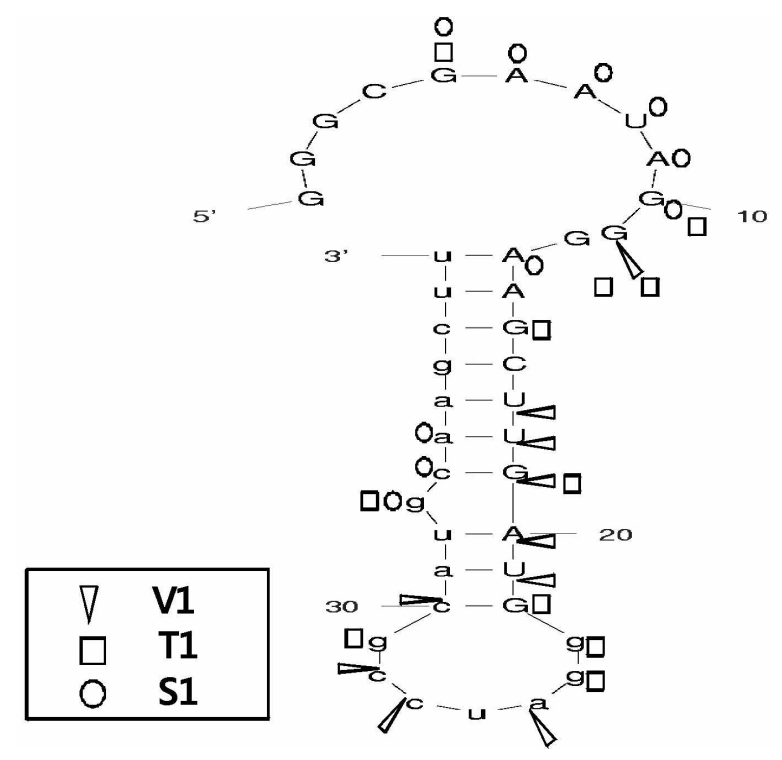

Figure 3. Schematic representation of possible secondary structure of R.VA aptamer 13-1-15. Triangles indicate the sites cleaved by RNase VI, squares indieate the sites cleaved by $R N$ ase $T l$ and circles indicate the sites cleaved by nuclease $\$ 1$.

A20, U21 and C 30 were cleaved by RNase V1, especially strong cleavages at region UI7UGI9 so these regions are thought to be located in double strand. But GII, $\mathrm{O} 25$ and C27C28 which were thought to be in single strand, were susceptible to RNase VI, suggesting that these regions were stacked from intramolecular interaction and became accessible to RNase $\mathrm{VI}$ in solution. Region $\Lambda 7 U \Lambda 9$ was protected from RNase V1 digestion by the hairpin RNA, a ligand used for selection of this RNA aptamer. This region of RNA aptamer $12-1-5$ is thought to be important for the interaction between the RNA aptamer and the hairpin RNA and this will be discussed later in footprinting assay.

Residues G5AAUA9 and G33 were cleaved by nuclease $\mathrm{SI}$, especially strong cleavages at $\mathrm{C} / \mathrm{O}$. so these regions are thought to be in single-strand region of the secondary structure model of RNA aplamer 13-1-15. The residue C 34 was susceptible to nuclease $\mathrm{SI}$ and residue $\mathrm{G} 19$ was attacked by RNase $\mathrm{T} 1$, and so $\mathrm{C} 34: \mathrm{G} 19$ base pair is thought to be unstable because of the adjacent presence of a bulge G33. This instability of C34:G19 base pair was also detected in C11:G25 base pair of RNA aptamer 13-1-3 and C $11: \mathrm{G} 24$ base pair of RNA aptamer $12-1-5^{6.7}$

In conclusion, the struclure of RNA aptamer 13-1-15 was analyzed in solution with probes such as RNase $\mathrm{TI}$, RNase $V 1$, and nuclease $S 1$ and its possible sccondary structuro was represented (Fig. 3). The result suggested that 1 ) this molecule has two single strand regions and one double strand region which has a bulge $\mathrm{G} 33$, and 2) $\mathrm{C} 34: \mathrm{G} 19$ base pair is unstable because of the adjacent presence of a bulge G33.

\section{Experimental Section}

Preparation of RNA. RNA aptamer 13-1-15 was synthesized by run-off in vitro transcription will 17 RNA polymerase from the DNA template to which the T7 promoter was anncaled and purified by gel clution of the crush and soak method. ${ }^{\text {(n) }}$ The resulting RNA was treated with CIP (calf intestinal alkaline phosphatase) to remove 5'terminal phosphate and then labeled at the $5^{\circ}$ end using $\left[\gamma^{32}{ }^{32}\right] \mathrm{ATP}^{2}$ and $\mathrm{T}^{4}$ polynucleotide kinase.

Enzymatic cleavage reaction. 5'-terminal radiolabeled RN $\triangle$ aptamer 13-1-15 was heated in binding buffer $(30 \mathrm{mM}$ Tris-acetate, $\mathrm{pH} 7.5,60 \mathrm{mM}$ magnesium acetate, $120 \mathrm{mM}$ potassium acetate, and $120 \mathrm{mM}$ ammonium acetate) at $37^{\circ} \mathrm{C}$ for $20 \mathrm{~min}$ and allowed to cool to RT $\left(-21^{\prime \prime} \mathrm{C}\right)$. Then $0 . \mathrm{I}-\mathrm{I}$ unit of nuclease S1 (Bochringer Manheim GmbH, W.-Germany) or 0.001-0.01 unit of RNase V1 (Pierce Molecular Biology, Perbio) or 0.1-1 unil of RNase T' (Industrial Rescarch Limited) was added to the above mixture and then the reaction mixture was incubated for $25 \mathrm{~min}$ al $\mathrm{RT}$. The reaction volume included an additional $1 \mathrm{mM} 7 . \mathrm{nCl}_{2}$ lor nuclease S1 cleavage. The cleavage products were recovered by ethanol precipitation and separated on a $15 \%$ polyacylamide gel in $90 \mathrm{mM}$ Tris-borate ( $\mathrm{pH} 8.3$ ) and $2.5 \mathrm{mM}$ EDTA containing $7 \mathrm{M}$ urea.

Acknowledgments. I thank Prof. Younghoon Lee (Department of Chemistry and Center for Molecular Design and Synthesis, Korca Advanced Institute of Science and Technology) for his helpful support in whose laboratory RNA labeling. experiment was pertormed

\section{References}

I. Lec, J.-H. Buhl. Korean (hem. Sis: 2008, 20,1937

2. Ko, J.-II.; Cho, B.; Alm, I. K.; I.ee. Y.: Park, I. Bull. Korem (hew soc: 1999,2ft,1335

3. Brumel, C., Romby, P. Msthods in themologe 2000, $31 \times, 3$

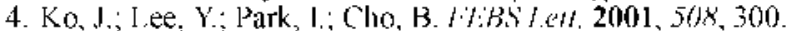

5. Clio, B. Bull. Korean (hem. Sise: 2006, 27,786.

6. Cho. B. Bull. Kowan (hem. Soc. 2007. 28,689.

7. Cho, B. Bull Korew (hem. tise 2008, 29, 1063.

8. Cho, B. Bull. Kowan (hem. Sox 2008, 20, 2026.

9. Latham, J.; Cech. T. Siefere 1989, $45,276$.

10. Stern, S.; Moazed, D.; Noller, II. Hethods Fizmol 1988 , 164.481

11. Muphy, F. L.: Cech. T. R. Biochmism 1993, 32, 529l.

12. Rangan, 1 ; : Masquida B.; Weshlor, t: Woodson. S. Proc Nal.

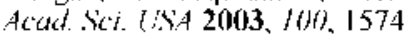

13. Tsai. H.; Masquida, B.; Biswas, R.; Westhof, E.; Gopalan, V. I. Mol. Brol. 2003, 325,661

14. Bartera, A.: Pan, T. RNA 2004, 10, 482.

15. Bergman, N.: Lau, V.; Lehnert, V. Westhof, E.; Bartel, D. P. RNA 2004, 10,176 .

16. Soukup. G. A.; Breaker, R. R. RNA 1999, 5, 1308

17. Li, Y. Breaker, R. R. J. Am. ('km. Sox: 1999,/2l, 5364

18. Mandal, M.: Breaker, R. R. Mot C'ell Biol. 2004, 5. 45I.

19. Shin, E. S : Hong, S. K : Cho, B. Bull. Korem them . Sos: 2008, 29. 2227

20. Sambrook, J.; Fritscl, f., F; Maniatis, T. Molecular (fong: A Lahoratory Mammot. 2nd ed: Cold Spring Harbor Laboratory Press: Cold Spring I larbor, NY, 1989. 